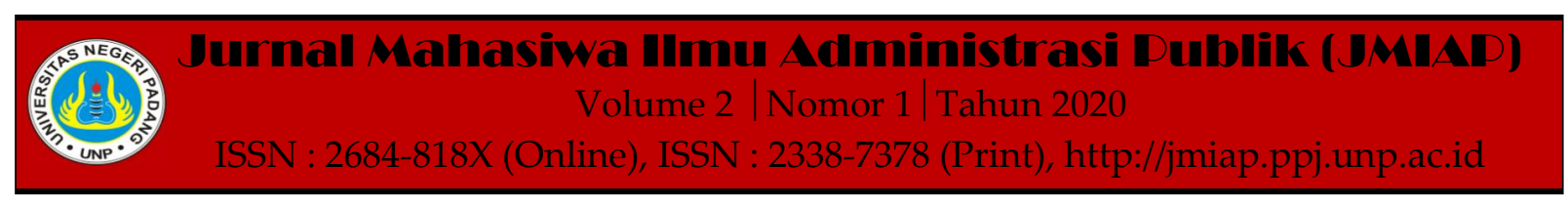

\title{
KENDALA DALAM PELAKSANAAN PROGRAM BANTUAN PELAMPUNG PADA NELAYAN KECIL DI KECAMATAN PADANG UTARA
}

\author{
Adrian Syahputra ${ }^{1(a)}$, Fitri Eriyanti ${ }^{2(b)}$ \\ ${ }^{1}$ Jurusan Ilmu Administrasi Negara, Universitas Negeri Padang \\ ${ }^{2}$ Jurusan Ilmu Administrasi Negara, Universitas Negeri Padang \\ a)adriansyahputra104@gmail.com, ${ }^{b)}$ fitri.eriyanti@fis.unp.ac.id
}

\begin{abstract}
This study is about the constraints of the life jacket program in improving the savety assurance of small fisherman in the District Of North Padang. The research method that researchers use is descriptive method and using qualitative approach. This research was conducted in the city of Padang, especially in the District Of North Padang by selecting informants using purposive sampling techniques. Data collected by observation, interview and documentation study. Data validity testing techniques with source triangulation. While the data analysis technique use data reduction techniques, data presentation dan conclusion drawing. The result of this study indicate there is a few constraints/problem of the life jacket program makes still not effective. The problem in this study is the low awareness of fisherman to mitigate or reduce the risk of their work, the low practicality of the life jacket so that many fishermen do not use them and the lack of supervision from the Padang City Marittime and Fisheries Offic which causes many fishermen who do not use life jacket so that there is no increase in guaratee their safety while at sea.
\end{abstract}

Keywords : Constraints, Life Jacket Assistance Program, Small Fisherman

Corresponding author. Email.adriansyahputra104@gmail.com, fitri.eriyanti@fis.unp.ac.id

How to cite this article. Syahputra, A \& Eriyanti, E. (2020). Kendala dalam Pelaksanaan Program Bantuan Pelampung pada Nelayan Kecil di Kota Padang. Jurnal Mahasiwa Ilmu Administrasi Publik (JMIAP) Jurusan Ilmu Administrasi Negara Fakultas Ilmu Sosial Universitas Negeri Padang, Volume 2 (1), Hal. 24-32.

http://jmiap.ppj.unp.ac.id

ISSN : 2684-818X (Online), ISSN : 2338-7378 (Print)

Copyright $\bigcirc 2020$. Published by Pusat Kajian-Pemberdayaan dan Pelayanan Masyarakat (PK-P2M) FIS UNP Padang 


\section{PENDAHULUAN}

Secara geografis, Indonesia terdiri dari dua pertiga wilayah perairan laut yang didalamnya terdapat lebih kurang 17.504 pulau. "Negara Kepulauan", begitulah Indonesia dikenal. Perairan laut Indonesia menyimpan berbagai macam ekosistem yang menjadi kekayaan tersendiri bagi negara Indonesia. Biota laut, terumbu karang, rumput laut dan lain-lain merupakan kekayaan laut Indonesia yang tak ternilai harganya. Keindahan bentang alam dan keelokan pemandanganya juga menjadi salah satu sumber pendapatan negara seperti dimanfaatkan sebagai obek wisata yang akan mendatangkan wisatawan domestik dan internasional sehingga menambah pendapatan negara Indonesia (Suparti, 2019:2).

Sebagai salah satu provinsi yang ada di Indonesia, Sumatera Barat terletak di pesisir barat pulau Sumatera. Luas daratan yang dimiliki provinsi Sumatera Barat adalah seluas $42.297,30 \mathrm{Km}^{2}$ atau sama dengan 2,17\% luas Indonesia. Sumatera Barat memiliki garis pantai sepanjang $2.420 .388 \mathrm{Km}$.

Ibukota dari provinsi Sumatera Barat adalah Kota Padang. Wilayah administratifnya seluas $694,96 \mathrm{Km}^{2}$. Kota ini memiliki jumlah penduduk sebanyak 927.168 jiwa (BPS, 2017). Kota Padang sebagai kota yang berbatasan dengan laut memiliki garis pantai sepanjang 99.632 $\mathrm{Km}$. Dengan keadaan ini, mengakibatkan banyaknya masyarakat Kota Padang yang memiliki pekerjaan sebagai nelayan, khususnya nelayan kecil. Tahun 2018, nelayan kecil di Kota Padang tersebar pada 7 (tujuh) kecamatan dengan jumlah sebanyak 7076 orang nelayan kecil (DKP Kota Padang).

Profesi nelayan merupakan salah satu profesi yang berisiko tinggi, hal ini disebabkan nelayan terus-menerus berada dalam kondisi bahaya tenggelam karena sifat laut yang tak dapat diduga ditambah dengan kemungkinan kecelakaan kapal yang akan dihadapai nelayan. Sebagai salah satu bentuk dari pengurangan risiko pekerjaan nelayan, Dinas Kelautan dan Perikanan Kota Padang melakukan suatu program bantuan pelampung (life jacket) kepada nelayan kecil di Kota Padang.

Kenyataan di lapangan masih terdapat beberapa kendala dalam implementasi program bantuan pelampung ini. Hal ini dikarenakan rendahnya kesadaran nelayan dalam upaya mitigasi risiko bahaya dari pekerjaan mereka, praktikalitas pelampung yang rendah sehingga tidak praktis jika digunakan saat melaut dan pengawasan yang belum maksimal dari DKP Kota Padang terhadap pelampung yang telah diberikan. Kendala-kendala ini membuat program bantuan pelampung ini belum efektif.

\section{TINJAUAN PUSTAKA \\ Konsep Efektivitas}

Menurut Gibson dalam Ahmad Subekti (2013:248) efektivitas merupakan kegiatan menilai yang diciptakan terkait keberhasilan organisasi maupun kelompok bahkan individu. Semakin sesuai keberhasilan mereka dengan keberhasilan yang diharapkan, penilaiannya semakin efektif.

Efektivitas juga berarti sebagai tolok ukur terkait gambaran seberapa jauh tujuan yang tercapai dibandingkan dengan yang diharapkan namun hanya terfokus kepada keluaran/hasil sedangkan terkait masukannya tidak terlalu diperhatikan. Kemudian, Yamit mengemukakan bahwa efektivitas sebagai suatu hal yang memberikan gambaran terkait sejauhmana tujuan yang tercapai, dilihat dari kualitas dan waktu yang digunakan yang memiliki orientasi pada keluaran/hasil dari suatu kegiatan (Sedarmayanti, 2014 Vol.3 No.12).

Jadi, dapat dipahami jika efektivitas adalah sebuah gambaran untuk mengetahui perbandingan antara pencapaian target yang telah dirumuskan sebelumnya dengan pencapaian target yang sebenarnya. Artinya semakin tinggi tingkat pencapaian target suatu kegiatan, maka efektivitasnya juga semakin tinggi. 
Untuk mengukur efektivitas program bantuan pelampung pada nelayan kecil menggunakan indikator efektivitas yang dikemukakan oleh Campbell (1989) yaitu :

1. Keberhasilan Sasaran.

2. Keberhasilan Program.

3. Tingkat Input dan Output.

4. Kepuasan Terhadap Program.

5. Pencapaian Tujuan Menyeluruh.

\section{Konsep Pemberdayaan Masyarakat}

Sulistiyani (2004) mengatakan bahwa pemberdayaan masyarakat adalah upaya menciptakan suasana yang membuat terjadinya kemungkinan potensi masyarakat untuk berkembang (enabling), karena pada dasarya tiap-tiap individu dalam masyarakat memiliki pasti memiliki daya walaupun dengan tingkatan daya yang berbeda-beda. Jika demikian, maka dapat diketahui bahwa pemberdayaan masyarakat adalah suatu proses kegiatan untuk mengembangkan daya yang dimiliki masyarakat dengan cara memotivasi atau membangkitkan kesadaran akan potensi yang dimiliki serta berusaha untuk mengembangkan daya atau potensi tersebut. Disamping itu, pemberdayaan juga harus mampu menciptakan masyarakat yang mandiri, bukan masyarakat yang memiliki ketergantungan pada si pemberdaya.

Pemberdayaan masyarakat memerlukan partisipasi aktif dari masyarakat karena telah difasilitasi dengan adanya pelaku pemberdayaan. Pemberdayaan masyarakat memiliki sasaran utama yaitu terhadap mereka yang lemah sehingga perlu untuk diberikan kekuatan atau kemampuan mengakses sumber daya produktif. Tujuan dari proses pemberdayaan masyarakat adalah untuk memberikan daya atau kekuatan agar terciptanya kemandirian pada masyarakat sehingga mampu meningkatkan kesejahteraan keluarganya dan memaksimalkan daya yang dimilikinya. Jadi dapat diketahui pemberdayaan masyarakat merupakan suatu proses menciptakan kemandirian pada masyarakat dengan cara memaksimalkan/pemberian daya kepada masyarakat khususnya kepada masyarakat yang kurang memiliki daya dengan memperhatikan agar tidak terjadi ketergantungan kepada pemberdaya sehingga didapatkan suatu masyarakat yang mandiri dan lebih sejahtera dari sebelumnya yang tentunya pemberdayaan masyarakat ini juga sangat tergantung kepada partisipasi aktif dari masyarakat yang akan diberdayakan.

\section{Konsep Pelampung}

Pelampung termasuk kedalam alat pelindung diri. Dalam Permenakertrans No. 8 tahun 2010, dijelaskan bahwa alat pelindung diri (APD) adalah alat yang mampu melindungi seseorang dari potensi bahaya di tempat kerja. Pelampung memiliki fungsi untuk melindungi orangorang yang bekerja atau beraktivitas dipermukaan air agar dapat terhindar dari bahaya tenggelam.

Syarat alat apung menurut SOLAS (1978) dalam Santara adalah memiliki daya apung dan stabilitas yang tinggi. Daya apung tersebut tidak boleh berkurang lebih dari 5\% setelah terendam air selama 24 jam, dilengkapi peluit untuk mengisyaratkan bahwa memerlukan bantuan, harus mampu mengangkat muka orang dari dalam air dan menahan di atas air, harus memiliki warna cerah agar mudah terlihat dan nyaman saat dipakai.

Berdasarkan penjelasan diatas, dapat diketahui bahwa pelampung merupakan suatu alat keselamatan kerja yang berguna untuk mencegah para pekerja di atas air agar tidak tenggelam dan mengurangi segala risiko bahaya yang mungkin diterima saat melakukan perkejaan di atas air tersebut salah satunya adalah bahaya tenggelam.

\section{Konsep Nelayan Kecil}

Menurut Retnowati (2011 Vol.XVI No.3) nelayan kecil sebenarnya adalah nelayan tradisional namun telah memiliki suatu modernisasi yaitu pada penggunaan diesel atau motor pada perahu mereka sehingga cakupan melaut dari nelayan kecil lebih luas daripada cakupan melaut nelayan 
tradisional, walaupun mereka tetap menggunakan perahu atau alat tangkap konvensional.

Undang-Undang No.7 tahun 2016 menyatakan bahwa nelayan kecil adalah nelayan yang melakukan penangkapan ikan untuk memenuhi kebutuhan sehari-hari, menggunakan kapal penangkap ikan berukuran paling besar 10 (sepuluh) gross ton (GT).

Berdasarkan paparan diatas, dapat diketahui bahwa nelayan kecil adalah masyarakat nelayan yang melakukan penangkapan ikan dilaut untuk memenuhi kebutuhan hidupnya sehari-hari yang menggunakan alat tangkap yang sederhana namun telah dilengkapi dengan mesin diesel agar cakupan wilayah penangkapan ikan lebih jauh, dan kapal yang digunakan nelayan kecil tidak melebihi ukuran 10 GT.

\section{METODE PENELITIAN}

Pendekatan yang digunakan dalam penelitian ini adalah pendekatan kualitatif, dan metode yang digunakan adalah metode deskriptif, bertempat di Kecamatan Padang Utara, Kota Padang. Pemberi informasi (informan) dipilih menggunakan teknik purposive sampling. Jenis data yang digunakan adalah data primer dan data sekunder. Teknik pengumpulan data dengan cara observation/pengamatan, interview dan documentation study. Uji keabsahan menggunakan teknik triangulasi sumber. Teknik analisis yang dipakai yaitu dari reduksi data, pengumpulan data hingga penarikan kesimpulan.

\section{HASIL DAN PEMBAHASAN}

\section{Efektivitas Program Bantuan Pelampung Pada Nelayan Kecil Di Kecamatan Padang Utara.}

Berdasarkan KAK (Kerangka Acuan Kerja) Pengadaan Pelampung (Life Jacket) Dinas Kelautan Dan Perikanan Kota Padang Tahun 2019, pelampung (life jacket) ini merupakan perengkat penyelamat yang paling vital saat terjadi kecelakaan dilaut. Perangkat ini di desain untuk membantu pengguna, baik secara sadar, maupun tidak sadar, untuk tetap mengapung di atas permukaan air atau ketika berada di laut. Dengan demikian pelampung ini adalah alat keselamatan yang harus ada dalam sebuah kapal laut, perahu atau alat transportasi laut, hal ini merujuk kepada Permenhub Nomor 25 tahun 2015 tentang Standar Keamanan Transportasi Sungai, Danau dan Penyeberangan harus memiliki alat penyelamat (pelampung).

Berkaitan dengan efektivitas program bantuan pelampung pada nelayan kecil di Kecamatan Padang Utara, dapat diukur menggunakan indikator efektivitas yang dikemukakan oleh Campbell (1989) yaitu sebagai berikut: 1) Keberhasilan Program, 2) Keberhasilan Sasaran, 3) Kepuasan Terhadap Program, 4) Tingkat Input dan Output, 5) Pencapaian Tujuan Menyeluruh.

a) Keberhasilan Program

Menurut Campbell

$(1989: 121)$ efektivitas suatu program sejalan dengan kemampuan operasional sebuah organisasi dalam melaksanakan program-program kerja yang sesuai dengan tujuan yang telah ditetapkan sebelumnya. Hal ini dapat ditinjau dari proses dan mekanisme suatu kegiatan yang dilakukan dilapangan. Berdasarkan penelitian yang telah dilakukan, program bantuan pelampung masih belum efektif, karena masih banyak nelayan yang telah mendapatkan bantuan pelampung, namun tidak menggunakan pelampung tersebut saat melaut sebagaimana mestinya, sehingga tidak terjadi peningkatan dalan penjaminan keselamatan nelayan saat melaut. Hal ini sesuai dengan penelitian Firdaus (2016) yang mengemukakan keberhasilan suatu program tergantung bagaimana program tersebut dapat dijalankan dan digunakan dengan tepat, serta dapat memberikan manfaat bagi masyarakat sebagai objek dari sebuah program. Kenyataannya pada program bantuan pelampung ini, pelaksanaan program belum sepenuhnya dapat bermanfaat bagi masyarakat khususnya bagi nelayan yang tidak menggunakan pelampung sebagaimana mestinya. 
b) Keberhasilan Sasaran

Menurut Campbell

$(1989: 121)$

keberhasilan sasaran dapat dilihat dengan difokuskan kepada output dari suatu program. Sebelumnya telah diketahui bahwa tujuan dari pemberian setiap bantuan kepada kelompok nelayan agar terjadi pemberdayaan di kelompok tersebut. Berbeda dengan bantuan-bantuan lain seperti mesin, jaring dan alat pancing yang bertujuan untuk meningkatkan perekonomian nelayan, pelampung dalam pemberdayaan berperan sebagai fasilitas atau alat penyelamat nelayan dari bencana atau kecelakaan sebagai sesuatu yang tidak diinginkan. Artinya pelampung berperan dalam pemberdayaan nelayan sebagai pencegah timbulnya hal-hal yang sangat merugikan bagi nelayan dan keluarganya. Sejalan dengan penelitian Khadafi (2019) yang menyatakan bahwa mayoritas nelayan merupakan kepala keluarga yang harus menafkahi anak, istri dan keluarganya. Ketika kepala keluarga meningga dunia, maka akan menyebabkan terjadinya masalah-masalah lain sebagai persoalan atau masalah turunannya seperti kemiskinan dan lain sebagainya. Disinilah peran pelampung untuk mencegah terjadinya kematian dari nelayan saat menghadapi bencana atau kecelakaan sehingga masalah turunan seperti kemiskinan tadi tidak terjadi. Keberhasilan sasaran tersebut belum tercapai karena masih banyak nelayan yang tidak menggunakan pelampung yang telah mereka dapatkan sehingga nelayan masih dalam risiko tinggi jika terjadi kecelakaan atau bencana saat melaut.

c) Kepuasan Terhadap Program

Starawaji (2009) menyatakan bahwa sebuah kepuasan terkait dengan kepuasan masyarakat terhadap tata cara penyelenggaraan sebuah program dan kepuasan masyarakat terhadap fasilitas yang ada dalam pengimplementasian suatu program yang dijalankan. Terkait dengan program bantuan pelampung, masyarakat nelayan masih belum puas terhadap pelampung yang diberikan karena terdapat kekurangan dari pelampung dilihat dari bentuk dan ukurannya yang membuat tingkat praktikalitasnya menjadi rendah, sehingga nelayan merasa kesulitan jika menggunakan pelampung saat melaut dan akhirnya memilih untuk tidak menggunakannya.

d) Tingkat Input dan Output

Menurut Campbell (1989) suatu program dikatakan efektif jika output atau keluaran yang dihasilkan dari sebuah program lebih besar daripada input atau masukan dari suatu program. Bantuan pelampung ini memang tidak memiliki peran jika tidak terjadi hal-hal berbahaya saat melakukan kegiatan di lautan seperti kecelakaan dan cuaca ekstrim, yang kemudian menjadikan output dari bantuan pelampung ini sama sekali tidak ada, namun keadaannya akan berbeda jika saat melakukan penangkapan ikan di laut terjadi hal-hal berbahaya seperti kecelakaan kapal atau cuaca ekstrim. Saat kejadian ini bantuan pelampung akan menghasilkan output yang sangat besar bahkan tak terhingga nilainya jika pelampung dapat menolong nelayan yang akan tenggelam dan berperan dalam menyelamatkan nyawa nelayan.

e) Pencapaian Tujuan Menyeluruh

Menurut Campbell (1989), pencapaian tujuan secara keseluruhan ini dilihat dari kesungguhan suatu organisasi dalam melaksanakan kegiatannya untuk mencapai keseluruhan tujuan yang telah ditetapkan sebelumnya. Dalam hal ini diupayakan melakukan penilaian umum terhadap sebanyak mungkin kriteria tunggal untuk menghasilkan penilaian efektivitas secara umum.

Dari penelitian terkait program bantuan pelampung ini, diketahui bahwa secara keseluruhan pencapaian tujuan dari program bantuan pelampung ini belum tercapai. Ini disebabkan karena masih terdapat kendala-kendala dalam mencapai tujuan yang telah ditetapkan sebelumnya. Terdapat beberapa tujuan dari penyelenggaraan program bantuan pelampung ini diantaranya adalah untuk 
meningkatkan penjaminan keselamatan nelayan saat melaut, penciptaan rasa safety pada nelayan saat melakukan proses penangkapan ikan, sebagai bentuk perhatian pemerintah terhadap masyarakat dan sebagai upaya pemberdayaan masyarakat lemah khususnya nelayan kecil. Pemberdayaan masyarakat ini lebih kepada pencegahan agar nelayan yang kebanyakan sebagai kepala kaluarga dapat terlindungi dari hal-hal berbahaya yang mungkin ditemui saat melakukan pekerjaan seperti kecelakaan kapan atau cuaca ekstrim sehingga diharapkan pelampung dapat bermanfaat saat nelayan mengalami hal yang tidak diinginkan saat berada di tengah laut.

Secara keseluruhan, pencapaian tujuan dari program bantuan pelampung ini belum sepenuhnya dapat dicapai dikarenakan masih banyaknya nelayan yang bahkan sama sekali tidak menggunakan pelampung saat melaut dengan berbagai alasan, sehingga keseluruhan tujuan-tujuan yang telah dirumuskan sebelumnya tidak dapat tercapai dengan baik.

\section{Kendala Dalam Pelaksanaan Program Bantuan Pelampung Pada Nelayan Kecil Di Kecamatan Padang Utara}

Kendala pertama terdapat dalam implementassi program bantuan pelampung ini adalah rendahnya kesadaran nelayan dalam upaya mengurangi risiko bahaya dalam pekerjaan mereka sebagai nelayan. Pada kenyataannya kesadaran memiliki peran penting dalam menyukseskan sebuah program. Seperti yang dipaparkan dalam penelitian Lestari terkait keberhasilan pelaksanaan program KB yang dikarenakan tingginya kesadaran pribadi dari pasangan usia produktif untuk ikut dalam berpartisipasi menyukseskan program ini sehingga program Keluarga Berencana di Desa Panggungharjo tersebut dapat terlaksana dengan baik. Dari penelitian diatas, dapat diketahui bahwa kesadaran masyarakat memiliki peran penting dalam menyukseskan sebuah program. Kesadaran inilah yang masih kurang dari nelayan penerima bantuan pelampung yang membuat belum berhasilnya program bantuan pelampung ini.

Kendala lainnya diketahui berasal dari bentuk dan ukuran pelampung itu sendiri yang dinilai menyulitkan saat dipakai saat melaut dan tidak praktis. Hal ini menunjukkan bahwa tingkat praktikalitas yang rendah dari pelampung sehingga membuat nelayan enggan untuk memakainya. Seperti yang dipaparkan dalam penelitian Nengsi (2017) tentang media pembelajaran yang menyatakan bahwa praktikalitas artinya memiliki sifat yang praktis atau tidak sulit untuk digunakan dan orang yang menggunakan merasa nyaman saat memakai sesuatu. Sehingga diharapkan bahwa suatu media pembelajaran haruslah memiliki praktikalitas yang tinggi sehingga mudah digunakan dan siswa senang dalam memakainya kemudian dapat memberikan manfaat secara optimal pada proses pembelajaran. Dari penelitian di atas, dapat diketahui bahwa produk apapun yang memiliki praktikalitas tinggi cenderung akan memberikan manfaat pada penggunanya karena pengguna senang saat menggunakannya. Praktikalitas inilah yang belum dimiliki oleh pelampung yang diberikan kepada nelayan sehingga nelayan merasa tidak praktis dan merasa pelampung hanya akan menyulitkan saat melakukan proses penangkapan ikan.

Kendala lain terkait dengan lemahnya pengawasan dari dinas terkait dengan bantuan pelampung yang telah diberikan, padahal pengawasan memiliki peran penting dalam keberhasilan sebuah program. Seperti yang dikemukakan dalam penelitian Sumual tentang upaya pengawasan dana Bantuan Operasional Sekolah (BOS) oleh Dinas Pendidikan di Kota Manado yang memiliki pengawasan yang lemah sehingga terjadi berbagai penyimpangan dalam pengelolaan dana BOS seperti penggunaan dana BOS untuk membiayai kegiatan diluar yang sudah ditentukan. Oleh karena itu efektifnya sebuah program memerlukan pengawasan 
yang memadai dari lembaga terkait. Dari penelitian diatas, dapat diketahui bahwa pengawasan memiliki peran penting dalam efektivitas sebuah program. Namun pengawasan inilah yang belum secara maksimal dilakukan oleh DKP Kota Padang terhadap nelayan penerima bantuan pelampung. Mengingat bahwa DKP Kota Padang hanya melakukan pengawasan ke lapangan hanya jika ada laporan kejanggalan yang terjadi di lapangan atau tidak dilakukan secara berkala, sehingga kurang efektifnya program bantuan pelampung ini.

Upaya Untuk Mengatasi Kendala Dalam Pelaksanaan Program Bantuan Pelampung Pada Nelayan Kecil Di Kecamatan Padang Utara

Terdapat beberapa upaya Dinas Kelautan Dan Perikanan Kota Padang dalam rangka mengatasi kendala yang terjadi di lapangan terkait program bantuan pelampung ini. Upaya pertama adalah tetap memberikan penyuluhan dan sosialisasi tentang pentingnya menggunakan pelampung saat melaut kepada nelayan walaupun sudah sering diberi tahu tentang hal tersebut, tetapi pemberian pemahaman itu tetap dilakukan oleh pihak DKP Kota Padang atau dari penyuluh perikanan di wilayah tersebut. Sejalan dengan penelitian Khadafi tahun 2019 yang menyatakan bahwa penyadaran akan pentingnya aspek keselamatan kerja bisa dilakukan dalam bentuk kegiatan sosialisasi kepada masyarakat nelayan meliputi presentasi dan diskusi, pembagian alat keselamatan berupa pelampung dan simulasi secara langsung dilapangan guna mengetahui apakah para nelayan menerapkan pengetahuan yang diberikan dengan baik.

Upaya kedua adalah dengan mengadakan monitoring dan evaluasi. Monitoring dan evaluasi yang serupa dengan pengawasan memang memiliki peran penting dalam menciptakan keberhasilan program seperti yang telah dikemukakan sebelumnya. Monitoring dan evaluasi didasarkan pada pengaduan atau adanya informasi yang membuat perlu untuk dilakukannya monitoring dan evaluasi seperti adanya pengaduan dari penyuluh atau dari nelayan lain di lapangan. Jika ditemukan kejanggalan seperti menemukan nelayan yang tidak menggunakan pelampung dan hanya menggantungkan pelampung dirumahnya, maka akan diancam untuk ditarik oleh pihak DKP Kota Padang.

\section{PENUTUP}

Setelah melakukan penelitian dan mendapatkan hasil dari penelitian serta telah melakukan pembahasan terkait hasil tersebut, maka dapat disimpulkan bahwa :

1. Efektivitas program bantuan pelampung pada nelayan kecil di Kecamatan Padang Utara setelah diukur dengan indikator efektivitas menurut Campbell (1989) ternyata belum efektif. Hal ini terkait dengan belum terpenuhinya indikator-indikator untuk mengukur efektivitas dalam program bantuan pelampung ini.

2. Kendala-kendala dalam implementasi program bantuan pelampung ini berupa rendahnya kesadaran nelayan untuk mitigasi/pengurangan risiko bahaya atas profesi yang mereka kerjakan, ukuran dan bentuk pelampung yang dinilai menyulitkan jika digunakan saat melaut dikarenakan pelampung yang memiliki ukuran yang besar dan disertai dengan tali yang membuat palampung sering tersangkut dengan jaring, dan pengawasan yang belum maksimal dari pihak dinas terkait.

3. Upaya yang dilakukan oleh dinas terkait yaitu DKP Kota Padang untuk mengatasi kendala-kendala yang ada adalah tetap memberikan penyuluhan dan sosialisasi pada nelayan tentang pentingnya menggunakan alat keselamatan (pelampung) saat melaut, melakukan monitoring dan evaluasi (monev) terkait bantuan yang telah diberikan yang didasarkan pada pengaduan dari penyuluh perikanan wilayah atau dari pengaduan nelayan 
yang melihat kejanggalan terkait bantuan yang diberikan.

Terkait hasil yang diperoleh dari penelitian yang telah dilakukan, peneliti memberikan beberapa saran, yaitu :

1. Terkait dengan sosialisasi manfaat pelampung yang dilakukan oleh penyuluh perikanan atau dinas terkait, peneliti menyarankan disamping memberikan penyuluhan atau sosialisasi terkait manfaat pelampung sebaiknya juga memberikan informasi berupa fakta-fakta terbaru yang berkaitan dengan tingginya risiko bahaya yang dihadapi oleh orang yang berprofesi sebagai nelayan, misalnya dengan menyampaikan berita-berita terkait dengan kapal nelayan yang tenggelam karena badai, atau dengan melihatkan video-video tentang kecelakaan kapal, sehingga lebih memunculkan rasa takut dan akhirnya membuat terjadinya keinginan untuk waspada dari diri nelayan sendiri sehingga akan lebih memperhatikan penggunaan pelampung saat melaut.

2. Terkait dengan monitoring dan evaluasi, sebelumnya monitoring dilakukan berdasarkan adanya informasi atau laporan-laporan kejanggalan dari penyuluh perikanan atau nelayan kemudian dilakukan monitoring. Sebaiknya monitoring sebagai tindakan pengawasan khususnya bantuan pelampung ini dilakukan secara berkala atau bahkan pengawasan secara mendadak, sehingga saat ditemui nelayan yang telah mendapatkan bantuan pelampung namun tetap tidak menggunakannya, dapat langung dikenakan sanksi berupa penarikan bantuan tersebut pada saat itu juga, intinya pengawasan dari pihak dinas harus lebih ditingkatkan lagi, mengingat kepedulian nelayan yang masih rendah terhadap risiko bahaya yang mungkin akan ditemuinya. Karena apabila pelampung tetap tidak digunakan secara maksimal oleh nelayan, program bantuan pelampung ini memang tidak akan ada manfaatnya, sehingga perlu adanya peningkatan pengawasan dari pihak dinas, jika biasanya melakukan pengawasan hanya satu kali dalam dua bulan, sebaiknya ditingkatkan menjadi satu kali sebulan atau bahkan lebih sering, dan juga diselingi dengan pengawasan mendadak agar nelayan merasa mereka memang diawasi oleh pihak dinas selaku pemberi bantuan.

\section{DAFTAR KEPUSTAKAAN}

Campbell. 1989. Riset Dalam Efektivitas Organisasi. Terjemahan Sahat Simamora. Jakarta: Erlangga.

Firdaus, Khonita. "Efektivitas Layanan "mLibrary" di Perpustakaan Gadjah Mada University". Universitas Airlangga.

Khadafi, Muammar. 2019. "Mitigasi Kecelakaan Kapal di Pelawangan Pantai Pencer Kecamatan Puger Kabupaten Jember". Jurnal Warta Pengabdian. Vol.13, No. 1.

Munawar, Noor. 2011. "Pemberdayaan Masyarakat". Jurnal Ilmiah CIVIS. Vol.1, No.2.

Permenakertrans No. 08 Tahun 2010 Tentang Alat Pelindung Diri.

Permenhub No 25 Tahun 2015 Tentang Standar Keamanan Transportasi Sungai, Danau dan Penyeberangan.

Pratiwi, Dwi Kurniawati. 2011. "Studi Pada Badan Pemberdayaan Masyarakat Kota Mojokerto tentang Pemberdayaan Masyarakat Di Bidang Usaha Ekonomi”. Jurnal Administrasi Publik. Vol.1, No. 4.

Retnowati, Endang. 2011. "Nelayan Indonesia Dalam Pusaran Kemiskinan Struktural (Perspektif Sosial, Ekonomi 
dan Hukum)". Jurnal Perspektif, Vol. XVI, No.3.

Santara, Adi Guna. 2014. "Peralatan Keselamatan Kerja Pada Perahu Slerek di PPN Pengambengan, Kabupaten Jembrana, Bali”. Jurnal IPTEKS PSP. Vol. 1, No.1.

Sulistiyani, Ambar Teguh. 2004. Kemitraan dan Model-Model Pemberdayaan. Yogyakarta: Gava Media.

Suparti. 2019. Mengenal Laut Indonesia. Tangerang: Loka Aksara.

Undang-Undang No. 45 Tahun 2009 Perubahan Atas Undang-Undang No. 31 Tahun 2014 TentangPerikanan.

Undang-Undang No.7 Tahun 2016

Tentang Perlindungan dan Pemberdayaan Nelayan, Pembudi Daya Ikan dan Petambak Garam.

Zulfa. "Efektivitas Program Desaku Menanti Bagi Warga Binaan Sosial (WBS) Di Kota Padang". Universitas Negeri Padang. 